\title{
EDUKASI PROTOKOL COVID 19 SEBAGAI ADAPTASI NEW NORMAL PADA SISWA SDIT AL MADINAH
}

\section{COVID 19 PROTOCOL EDUCATION AS A NEW NORMAL ADAPTATION FOR SDIT AL MADINAH STUDENTS}

\author{
Wuri Utami $^{1 *}$, Nurlaila ${ }^{2}$, Rina Saraswati ${ }^{3,}$ Khusnul Dwi Haryani ${ }^{4}$, Rizki Intan Nur Fajrin ${ }^{5}$, \\ Citra Ayu Salma Fuaida ${ }^{6}$ \\ $\mathbf{1 , 2 , 3 , 4 , 5 , 6}$ Universitas Muhammadiyah Gombong \\ Email: utamiwuri@gmail.com¹, ellaimut@gmail.com², dissaras@gmail.com 3, \\ khusnul@gmail.com ${ }^{4}$,rizki@gmail.com ${ }^{5}$, citra@gmail.com ${ }^{6}$ \\ *Corresponding author: utamiwuri@gmail.com ${ }^{1}$
}

Kata Kunci: edukasi protocol covid 19 ;adaptasi new normal ;siswa sd

Kata Kunci: edukasi protocol covid 19

;adaptasi new normal ;siswa sd
Pemerintah melalui Kementerian Pendidikan dan Kebudayaan telah mengeluarkan keputusan untuk mengizinkan kegiatan tatap muka di sekolah dimulai pada Januari 2021 mendatang. Mengacu kepada keputusan tersebut, tentunya diperlukan kesiapan yang matang bagi semua pihak untuk mempersiapkan secara menyeluruh aspek kesehatan yang dibutuhkan, khususnya bagi pelajar yang akan memulai kegiatan tatap muka di sekolah. Berdasarkan data terkini dari Ikatan Dokter Anak Indonesia (IDAI), proporsi anak-anak terinfeksi virus Corona sebesar 11,3 persen. Risiko anak terkena virus Corona lebih rendah, bukan berarti kewaspadaan terhadap hal tersebut hilang. Banyak hal yang perlu dipersiapkan untuk memulai sekolah tatap muka. Tujuan pengabdian masyarakat ini adalah memberikan edukasi protokol Covid 19 sebagai adaptasi new normal pada siswa SDIT Al. Madinah Kebumen. Metode pelaksanaan pengabdian masyarakat ini ceramah dan simulasi dengan secara langsung dan audio visual. Hasil dari kegiatan ini terdapat peningkatan pengetahuan dibuktikan dengan nilai rata-rata pre test 76,1 dan rata-rata nilai post test 85,71 disertai antusiasme yang tinggi dari siswa-siswi dengan dibuktikan mampu mensimulasikan protocol Covid 19 dengan benar. Kesimpulan dari kegiatan pengabdian masyarakat ini ada peningkatan pengetahuan protokol Covid 19 sebagai adaptasi new normal pada siswa SDIT Al. Madinah Kebumen

\section{ABSTRACT}

The government through the Ministry of Education and Culture has issued a decision to allow faceto-face activities at schools to start in January 2021. Referring to the decision, of course, it requires careful readiness for all parties to thoroughly prepare the health aspects needed, especially for students who will start face-to-face activities at school. Based on the latest data from the Indonesian Pediatrician Association (IDAI), the proportion of children infected with the Corona virus is 11.3 percent. The risk of children being exposed to the Corona virus is lower, it does not mean that awareness about it is lost. Many things need to be prepared to start face-to-face school. The purpose of this community service is to provide education on the Covid 19 protocol as a new normal adaptation to SDIT Al students. Medina Kebumen. The method of implementing this community service is lectures and simulations directly and audio-visually. The results of this activity there was an increase in knowledge as evidenced by the average pre-test score of 76.1 and the average post-test score of 85.71 accompanied by high enthusiasm from students, as evidenced by being able to simulate the Covid 19 protocol correctly. The conclusion from this community service activity is that there is an increase in knowledge of the Covid 19 protocol as a new normal adaptation for SDIT Al Madinah Kebumen students 



\section{PENDAHULUAN}

Angka pasien Covid-19 dari hari ke hari selalu mengalami peningkatan, diketahui pada bulan Oktober 2020 total seluruh jumlah pasien Covid-19 di dunia mencapai 36.002,827 kasus. Di Indonesia sendiri angka pasien Covid-19 total kasus mencapai 320.564 kasus terkonfirmasi, 244.060 kasus sembuh, 11.580 kasus meninggal (Kemenkes RI, 2020). Jawa Tengah mencapai 25,261 total kasus, data terbaru seluruh pasien Covid-19 di Kebumen mencapai 901 kasus, 273 sedang dalam perawatan, 611 pasien sembuh dan, 23 pasien meninggal. Kasus Covid 19 pada anak di kabupaten Kebumen mencapai 418 kasus pada bulan Januari 2021 (corona.kebumen.go.id.2021)

Faktor penyebab kejadian covid-19 kian meningkat disebabkan karena kurangnya kesadaran masyarakat, masyarakat masih belum sadar terhadap apa yang harus dilakukan dan tidak dilakukan untuk pencegahan Coronavirus ini. Fakta menunjukkan masih banyak kelompok masyarakat yang mengabaikan peraturan physical distancing, atau isolasi mandiri, larangan berkumpul dan tidak rajin melakukan cuci tangan sehingga penularan terus menerus terjadi (Ilpaj \& Nurwati, 2020).

Pemerintah melalui

Kementerian Pendidikan dan

Kebudayaan telah mengeluarkan keputusan untuk mengizinkan kegiatan tatap muka di sekolah dimulai pada Januari 2021 mendatang. Mengacu kepada keputusan tersebut, tentunya diperlukan kesiapan yang matang bagi semua pihak untuk mempersiapkan secara menyeluruh aspek kesehatan yang dibutuhkan, khususnya bagi pelajar yang akan memulai kegiatan tatap muka di sekolah (Liputan 6.com).

Komitmen seluruh pihak untuk memutus rantai penularan. Pemerintah khususnya pemerintah daerah harus menyiapkan aturan protokol kesehatan yang ketat untuk sekolah. Screening protokol kesehatan dari mulai suhu tubuh hingga menerapkan 3M, sekolah juga perlu mengatur jumlah siswa yang akan masuk di dalam kelas. Kapasitas bisa dikurangi hingga $25 \%$ saja yang bisa belajar di kelas, hal ini penting untuk menjaga jarak bagi setiap anak di kelas. Serta guru harus berperan aktif sebagai petugas kesehatan yang sigap. Banyak orang tua yang khawatir penularan dari virus corona di sekolah atau saat anak mereka berangkat dan pulang dari sekolah, hal ini terjadi karena belum semua anak paham mengenai pentingnya mematuhi protocol Covid 19.

Berdasarkan permasalahan yang terjadi di atas, maka diperlukan penyuluhan edukasi protokol Covid 19 sebagai adaptasi new normal pada siswa SDIT Al. Madinah Kebumen.

\section{METODE}

\section{Tahap Persiapan}

Pada tahap persiapan, team melakukan studi pendahuluan dan survey berkaitan dengan 
kebutuhan sekolah tentang program pengabdian. Team juga melakukan Koordinasi dengan Kepala Sekolah SDIT Al.Madinah Kebumen terkait rencana kegiatan yang akan dilakukan.

\section{Tahap Pelaksanaan}

Pada tahap pelaksanaan, team bersama pihak sekolah melakukan koordinasi untuk mengatur teknis pelaksanaan edukasi dengan penerapan protokol Covid 19. Dalam pelaksanaannya team bertugas sebagai fasilitator dan menghadirkan pemateri serta mengawal jalannya kegiatan dari awal hingga usai. Pihak sekolah SDIT. Al Madinah Kebumen selaku mitra berwenang membantu mengkoordinasikan kegiatan serta menyediakan tempat dan perlengkapan yang dibutuhkan selama kegiatan.

\section{Tahap Evaluasi dan RTL}

Sebagai evaluasi, dilakukan assessment baik secara kognitif melalui pre-post test maupun psikomotor melalui simulasi dan praktek. Setelah program pengabdian selesai, kegiatan dilanjutkan dengan penyusunan laporan untuk diserahkan kembali ke LPPM.

Sebagai rencana tindak lanjut dari kegiatan ini adalah sekolah memberikan edukasi protokol Covid 19 pada saat orientasi awal saat sekolah mulai pembelajaran kembali di semester ganjil tahun akademik 2021/2022 dan memasang poster edukasi protokol Covid 19.

\section{HASIL DAN PEMBAHASAN}

Kegiatan pengabdian kepada masyarakat ini dilaksanakan dalam bentuk penyuluhan. Tahap kegiatan tersebut meliputi:

Persiapan kegiatan dilaksanakan dengan melakukan koordinasi dengan Kepala Sekolah SDIT Al. Madinah Kebumen. Pada kegiatan persiapan Tim pengabdian melakukan pertemuan dengan pembahasan mengenai teknik kegiatan dan pembagian tugas masing- masing. Tim pengabdian juga melakukan kegiatan persiapan materi berupa kuesioner, leaflet, video edukasi dan poster pendukung kegiatan.

Kegiatan pengabdian telah dilakukan sebanyak 5x. Adapun jenis kegiatan diantaranya: Pada 01 Maret 2021 Pre test dan penyuluhan pengetahuan mengenai Covid 19 dengan topik: Definisi, penyebab, tanda gejala dan pencegahan Covid 19 di sampaikan oleh Wuri Utami, M.Kep. Selanjutnya pada 02 Maret 2021 Penyuluhan dan simulasi ke siswa/siswi dan pihak sekolah dengan topik: Protokol Covid 19 yang disampaikan oleh Nurlaila , M.Kep, kemudian 03 Maret 2021 Simulasi ke siswa/siswi dan pihak sekolah dengan topik: Tatalaksana protokol pencegahan Covid 19 yang disampaikan oleh Rina Saraswati, M.Kep dan selanjutnya 05 Maret 2021 Evaluasi kegiatan Post Test yang di pandu oleh team dan mahasiswa.

Evaluasi kegiatan pengabdian dilakukan sebagai upaya untuk mengukur ketercapaian program kegiatan yang telah dilaksanakan. Evaluasi kegiatan dalam program pengabdian ini meliputi: 
Evaluasi terhadap tingkat pengetahaun siswa mengenai protokol dan pencegahan Covid 19 dilakukan melalui kegiatan pre test dan post test. Hal ini dilakukan karena sebagai upaya bagi tim kegiatan untuk memastikan terjadi peningkatan pengetahuan setelah program dilakukan. Tingkat pengetahuan siswa ini penting karena dengan memiliki tingkat pengetahuan yang baik mengenai protocol dan pencegahan Covid 19 diharapkan siswa dapat menerapakan protokol dan pencegahan Covid 19, sehingga diharapkan dapat membantu mengurangi dan mencegah terjadinya penularan Covid 19. Hasil kegiatan pre-post tes dapat dilihat pada tabel 1:

Tabel 1: Pre Test dan Post Test pengetahuan siswa SDIT Al.Madinah Kebumen

Periode 1:

\begin{tabular}{|c|c|c|}
\hline No & Pre Test & Post Test \\
\hline 1 & 80 & 90 \\
\hline 2 & 70 & 90 \\
\hline 3 & 90 & 100 \\
\hline 4 & 70 & 80 \\
\hline 5 & 70 & 70 \\
\hline 6 & 70 & 80 \\
\hline 7 & 80 & 90 \\
\hline 8 & 90 & 75 \\
\hline 9 & 70 & 90 \\
\hline 10 & 80 & 90 \\
\hline 11 & 70 & 80 \\
\hline 12 & 80 & 80 \\
\hline 13 & 70 & 90 \\
\hline 14 & 90 & 90 \\
\hline 15 & 80 & 90 \\
\hline 16 & 80 & 90 \\
\hline 17 & 80 & 90 \\
\hline 18 & 80 & 90 \\
\hline 19 & 90 & 90 \\
\hline 20 & 60 & 90 \\
\hline 21 & 50 & 70 \\
\hline 22 & 90 & 90 \\
\hline 23 & 80 & 90 \\
\hline 24 & 70 & 90 \\
\hline 25 & 70 & 70 \\
\hline 26 & 70 & 90 \\
\hline 27 & 80 & 90 \\
\hline 28 & 80 & 90 \\
\hline 29 & 80 & 90 \\
\hline 30 & 80 & 90 \\
\hline
\end{tabular}




\begin{tabular}{|l|l|l|}
\hline 31 & 80 & 90 \\
\hline 32 & 70 & 80 \\
\hline 33 & 50 & 90 \\
\hline 34 & 60 & 60 \\
\hline 35 & 50 & 70 \\
\hline 36 & 80 & 70 \\
\hline 37 & 90 & 90 \\
\hline
\end{tabular}

Periode 2:

\begin{tabular}{|c|c|c|}
\hline No & Pre Test & Post Test \\
\hline 1 & 70 & 90 \\
\hline 2 & 70 & 90 \\
\hline 3 & 80 & 80 \\
\hline 4 & 90 & 90 \\
\hline 5 & 60 & 60 \\
\hline 6 & 80 & 80 \\
\hline 7 & 70 & 90 \\
\hline 8 & 80 & 90 \\
\hline 9 & 50 & 90 \\
\hline 10 & 70 & 80 \\
\hline 11 & 60 & 70 \\
\hline 12 & 70 & 80 \\
\hline 13 & 80 & 100 \\
\hline 14 & 80 & 90 \\
\hline 15 & 80 & 100 \\
\hline 16 & 80 & 80 \\
\hline 17 & 80 & 80 \\
\hline 18 & 80 & 90 \\
\hline 19 & 80 & 90 \\
\hline 20 & 70 & 70 \\
\hline 21 & 70 & 90 \\
\hline 22 & 80 & 90 \\
\hline 23 & 60 & 80 \\
\hline 24 & 90 & 90 \\
\hline 25 & 80 & 80 \\
\hline 26 & 80 & 90 \\
\hline 27 & 70 & 100 \\
\hline 28 & 80 & 90 \\
\hline 29 & 90 & 90 \\
\hline 30 & 80 & 70 \\
\hline 31 & 80 & 90 \\
\hline 32 & 80 & 100 \\
\hline 33 & 90 & 90 \\
\hline 34 & 80 & 80 \\
\hline 35 & 70 & 70 \\
\hline 36 & 80 & 80 \\
\hline
\end{tabular}




\begin{tabular}{|c|c|c|}
\hline 37 & 80 & 90 \\
\hline 38 & 100 & 100 \\
\hline 39 & 80 & 90 \\
\hline
\end{tabular}
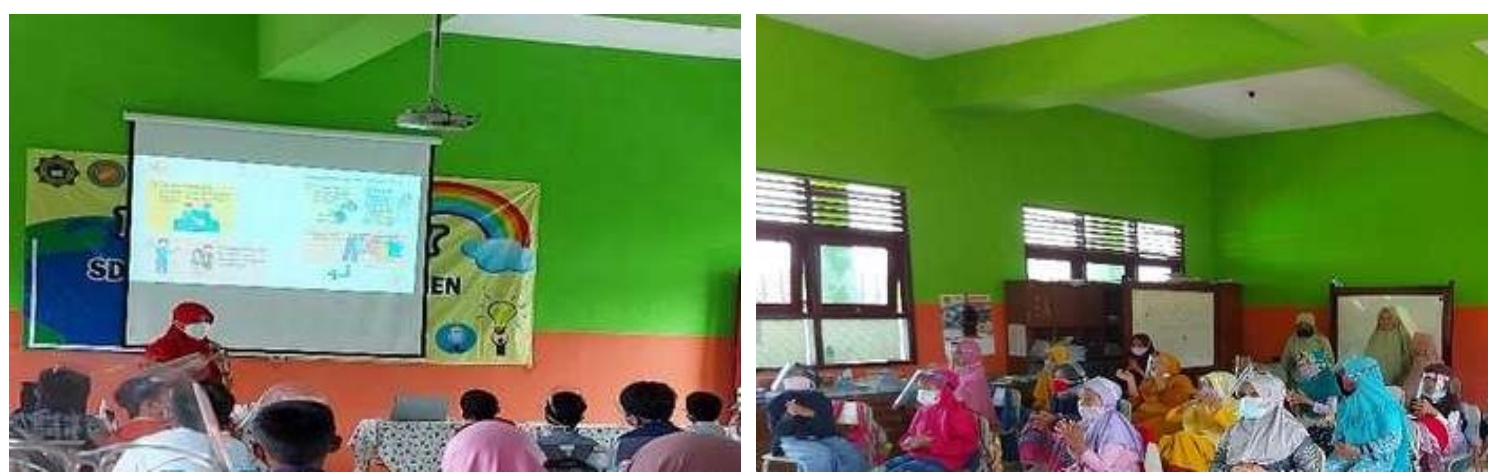

Gambar 1: Pelaksanaan Kegiatan

\section{SIMPULAN}

Edukasi protokol Covid 19 sebagai adaptasi new normal pada siswa SDIT Al. Madinah Kebumen dilakukan dengan penyuluhan dan latihan simulasi protokol Covid 19 dengan praktek menggunakan dan melepas masker dengan benar, cuci tangan 6 benar dengan sabun dan hand rub, serta cara menjaga jarak saat ngobrol dan makan snack saat istirahat. Evaluasi ini dilakukan dengan cara di contohkan, menyimak video simulasi dan selanjutnya siswa melakukan simulasi sesuai contoh yang di lihat. Hasilnya siswa sudah mampu melakukan simulasi protokol Covid 19 dengan benar.

Rencana tindak lanjut dari kegiatan ini adalah sekolah memberikan edukasi protokol Covid 19 pada saat setiap orientasi awal saat sekolah mulai pembelajaran kembali di semester ganjil tahun akademik 2021/2022 dan memasang poster edukasi protokol Covid 19.

\section{DAFTAR PUSTAKA}

Anies. (2020). Covid-19 Seluk Beluk Corona Virus. ARRUZ MEDIA

Firmansyah, Y., \& Kardina, F. (2020). Pengaruh New Normal Ditengah Pandemi Covid-19 Terhadap Pengelolahan Sekolah Dan Peserta Didik. Buana Ilmu, 4(2), 99-112. https://doi.org/10.36805/bi.v4 i2.1107.

Habibi, A. (2020). Normal Baru Pasca Covid-19. Journal.Uinjkt.Ac.Id， 4(1), 197-202.

http://journal.uinjkt.ac.id/inde x.php/adalah/article/view/158 09 
Tanggapan COVID-19 Provinsi Jawa Tengah. (2020, Oktober 9). Sebaran Kasus COVID-19 di Jawa Tengah. https://corona.jatengprov.go.i d/

WHO. (2020). Pertanyaan jawaban terkait COVID-19 untuk publik.(n.d). Retrieved Oktober 8, 2020, Fromhttps://www.who.int/ind onesia/news/novelcoronavirus/qa-for-public

Worldometer.info. (2020, Oktober 10). COVID-19 Coronavirus Pandemic.

https://www.worldometers.inf o/coronavirus/country/indone sia/

Persiapan-sekolah tatap muka di tengah pandemi covid 19. (2020). https://www.liputan6.com/citi zen6/read/4425806/ 